3 Tominaga A, Takaki S, Koyama N, Katoh S, Matsumoto $\mathrm{R}$, Migita $\mathrm{M}$, et al. Transgenic mice expressing a $B$ cell growth and differentiation factor gene (interleukin 5) develop eosinophilia and autoantibody production. $\mathcal{f}$ Exp Med 1991;173:429-37.

4 Sanderson CJ, Campbell HD, Young IG. Molecular and cellular biology of eosinophil Molecular and cellular biology of eosinophil
differentiation factor (interleukin-5) and its differentiation factor (interleukine $\mathrm{B}$ cells. Immunol effects on human and
Rev 1988;102:29-50.

5 Barnes L, Rodnan GP, Medsger TA, Short D. Eosinophilic fasciitis. A pathologic study of twenty cases. Am ₹ Pathol 1979;96:493-518.

6 Rosenthal J, Benson MD. Diffuse fasciitis and eosinophilia with symmetric polyarthritis. Ann Intern Med 1980;92:507-9.

7 Matsumoto R, Ando M, Kohrogi $H$, Araki S, Takatsu K. Interleukin-5 levels of pleural fluid and serum Interleukin-5 levels of pleural fluid drome. Chest 1992;102:1296-7.

8 Hirashima M, Ueno M, Higuchi S, Matsumoto $\mathrm{T}$, Sakata KM, Matsumoto R, et al. Establishment of a human T-cell line constitutively producing several eosinophil chemotactic lymphokines and their functional heterogeneity on eosinophils. Lymphokine Cytokine Res 1992; 11:331-8.

9 Kopf M, Brombacher F, Hodgkin PD, Ramsay AJ, Milbourne EA, Dai WJ, et al. IL-5deficient mice have a developmental defect in CD5 + B-1 cells and lack eosinophilia but have normal antibody and cytotoxic $T$ cell responses. Immunity 1996;4:15-24.

10 Meeker TC, Hardy D, Willman C, Hogan T, Abrams J. Activation of the interleukin-3 gene by chromosome translocation in acute lymphocytic leukemia with eosinophilia. Blood 1990;76:285-9.

\section{Incidence of hepatitis induced by non-steroidal anti-inflammatory drugs (NSAID)}

Netter et al ${ }^{1}$ reported the incidence of hepatitis due to NSAID after a French drug surveillance study in $1985 .^{2}$ This work, which is regularly cited in reference books and other publications, ${ }^{34}$ has been updated with the results of a second cooperative study carried out in the same way, by the same team, to compare and measure any changes in risk after a three year interval. As we have pointed out, ${ }^{5}$ this approach should minimise the bias inherent in such studies of drug surveillance.

In 1989 the drug surveillance centres collected 51 cases ( 30 women and 21 men) [the comparable figures for 1985 were 56 cases-37 women and 19 men] of hepatitis associated with NSAID in patients without any previous history of hepatic disorder. They comprised acute cytolytic hepatitis (7)

Changes in incidences of hepatitis (cases per months of treatment) due to NSAID in France

\begin{tabular}{|c|c|c|c|}
\hline \multirow{2}{*}{ Group } & \multirow{2}{*}{$\begin{array}{l}\text { Incidence of } \\
\text { hepatitis }\end{array}$} & \multicolumn{2}{|l|}{ NSAID } \\
\hline & & 1985 & 1989 \\
\hline 1 & $>1 / 50000$ & Oxyphenbutazone & \\
\hline 2 & $\begin{array}{l}1 / 50000 \text { to } \\
1 / 100000\end{array}$ & Isoxicam, pirprofen, sulindac & Pirprofen, fenbufen, phenylbutazone \\
\hline 3 & $\begin{array}{l}1 / 100000 \text { to } \\
1 / 300000\end{array}$ & $\begin{array}{l}\text { Fenbufen, ibuprofen, indomethacin, } \\
\text { ketoprofen }\end{array}$ & $\begin{array}{l}\text { Ketoprofen, sulindac, diclofenac, } \\
\text { mefenamic acid }\end{array}$ \\
\hline 4 & $\begin{array}{l}1 / 300000 \text { to } \\
1 / 500000\end{array}$ & Diclofenac, piroxicam & Ibuprofen, etodolac, piroxicam, tenoxicam \\
\hline 5 & $<1 / 500000$ & $\begin{array}{l}\text { Flurbiprofen, sodium naproxen, } \\
\text { niflumic acid, tiaprofenic acid }\end{array}$ & $\begin{array}{l}\text { Indomethacin, sodium naproxen, niflumic } \\
\text { acid, tiaprofenic acid, fenoprofen }\end{array}$ \\
\hline
\end{tabular}

[24], acute cholestatic hepatitis (17) [9], or mixed hepatitis (7) [15]. The remainder were subclinical biochemical abnormalities (20) [8]

In 1989 all patients recovered after the drug was stopped [in 1985 three patients died].

On the basis of the later study, NSAID were reclassified according to the incidence of hepatitis expressed as the number of cases per months of treatment, and the 1985 and 1989 classifications are compared (table).

It is noteworthy that: (a) two drugs in groups 1 and 2 in 1985 were withdrawn from the market that year: oxyphenbutazone because of haematological toxicity and isoxicam because of skin toxicity; (b) pirprofen, which was eventually withdrawn (in 1990) because of hepatic toxicity with, according to the manufacturer, ${ }^{6}$ a frequency of one case per 69000 months of treatment, was in group 2 in both of our studies; (c) piroxicam and tenoxicam, which were put on the market at different times (1981 and 1988 respectively), were both in group 4 in 1989 .

The hepatotoxicity of NSAID has been the subject of reports for some years. ${ }^{4}$ From these reports and our pair of studies emerge a number of broad ideas about NSAID induced hepatotoxicity:

- side effects are non-negligible, with regard to either morbidity or mortality

- different chemical structures can produce similar hepatotoxic responses

- older women greatly predominate among affected patients

- a hepatotoxic response is unpredictable and sometimes is unaccompanied by symptoms

- when a drug is reintroduced, side effect is frequently more sudden and severe, thus the readministration of the same drug must be strictly avoided

- these hepatotoxicities are difficult to inves- tigate for a number of reasons: blood test findings are extremely variable and may show cytolytic, cholestatic, or mixed pattern effects; the clinical picture may or may no suggest an immunoallergic response; the histology is rarely pathognomonic; and, finally, little is known about the mechanisms that initiate it, and little basic research has been done on the subject.

PHILIPPE TRECHOT PIERRE GILLET GERARD GAY BERNADETTE HANESSE PATRICK NETTER

Centre de Pharmacovigilance de Nancy

ANNE CASTOT

Centre de Pharmacovigilance de Paris Fernand-Widal

DOMINIQUE LARREY Hôpital Saint Eloi Montpellier

1 Netter P, Castot A, Larrey D, Carlier P, Bannwarth B, Tréchot P. Hepatitis induced by non-steroidal anti-inflammatory drugs. Ann Rheum Dis 1989;48:439.

2 Castot A, Netter P, Larrey D, Carlier P, Gaire $M$, Bannwarth B. Hépatites aux antiinflammatoires non stéroidiens. Bilan coopératif des Centres Régionaux de pharmacovigilance pour l'année 1985. Therapie 1988; 43:229-3.

3 O'Brien WN. Hepatitis due to non-steroidal anti-inflammatory drugs (NSAIDs). In: Rainsford KD, Velo GP, eds. Side-effects of antiinflammatory drugs. Lancaster: Kluwer Academic Publishers, 1992:211-22.

4 Stricker BHCH. Drug-induced hepatic injury. In: Dukes MNG ed. Drug-induced disorders. Amsterdam: Elsevier Science Publishers, 1992:93-149.

5 Tréchot P, Moore N, Bresler N, Castot A, Gay G, Netter P, Royer R. Potassium chloride tab$\mathrm{G}$, Netter $\mathrm{P}$, Royer $\mathrm{R}$. Potassium chloride tablets and small bowel stenoses and perforations: system. Am $\mathcal{f}$ Gastroenterol 1994;89:1268.

6 Anonymous. Arrêt de la commercialisation de Rangasil. Rev Prescr 1990;10:243. 